\title{
The Effect of Starter Cultures on the Portuguese Traditional Sausage "Paio do Alentejo" in Terms of Its Sensory and Textural Characteristics and Polycyclic Aromatic Hydrocarbons Profile
}

\author{
Elias, M. ${ }^{1}$, Potes, M. E. ${ }^{1}$, Roseiro, L. C. ${ }^{2}$, Santos, C. ${ }^{2}$, Gomes, A. ${ }^{2}$, \& Agulheiro-Santos, A. C. ${ }^{1}$ \\ ${ }^{1}$ Universidade de Évora, Escola de Ciências e Tecnologia e Instituto de Ciências Agrárias e Ambientais \\ Mediterrânicas, Apartado 94, 7002 - 554 Évora, Portugal \\ ${ }^{2}$ Instituto Nacional de Investigação Agrária e Veterinária, I.P., Campus do IAPMEI (Edifício S), Estrada do \\ Paço do Lumiar, 22, 1649-038 Lisboa, Portugal \\ Correspondence: Elias, M., Universidade de Évora, Escola de Ciências e Tecnologia e Instituto de Ciências \\ Agrárias e Ambientais Mediterrânicas, Apartado 94, 7002 - 554 Évora, Portugal. E-mail: elias@uevora.pt
}

Received: January 3, 2014 Accepted: March 8, 2014 Online Published: April 2, 2014

doi:10.5539/jfr.v3n3p45 URL: http://dx.doi.org/10.5539/jfr.v3n3p45

\begin{abstract}
"Paio do Alentejo" is a Portuguese dry-cured sausage, made with meat from the Alentejano pig breed. The main aim of this study is to evaluate the benefits of the use of starter cultures on the quality of the sausage, mainly with regard to its sensory properties, rheological characteristics and PAH profile.

Three batches of the product were examined: S1-inoculated with a commercial starter comprising Lactobacillus spp., Micrococcaceae and yeasts; S2-inoculated with a starter comprising Lactobacillus sakei and Staphylococcus xylosus; C-the control batch, was not inoculated.

A sensory panel of 12 experts analysed samples in accordance with a descriptive analysis using a structured scale. A Texture Profile Analysis and 16 EPA priority PAHs for dry fermented sausages were performed.

Both inoculated batches were well received by the judges, no significant differences being noted between them. The use of S2 led to a slight improvement in terms of cohesiveness. However, the use of starter cultures was not found to influence PAH content.
\end{abstract}

Keywords: sensory properties, TPA, PAHs, Portuguese dry sausage, starter cultures

\section{Introduction}

In Mediterranean countries the consumption of dry-cured sausages is widespread, and in Portugal one of the most popular is "Paio". "Paio do Alentejo" is a commercial high-value product, manufactured using traditional ingredients and employing modern technology, and is usually produced without using starter cultures.

It is produced in the Alentejo region of south-east Portugal and is made with meat from the Alentejano pig breed, a Portuguese autochthonous breed produced in the Alentejo region, similar to the Iberian pig breed, whose meat is known for its high content of intra- and inter-muscular fat, which is rich in oleic acid (Elias \& Carrascosa, 2010).

Starter cultures were first used in the early $20^{\text {th }}$ century to improve food safety. Nowadays, they are used in order to achieve other kinds of improvement associated with, for example, sensorial, nutritional, safety and technological characteristics, and their use has been widely demonstrated to lead to benefits in terms of final product quality (Bover-Cid et al., 1999; Bover-Cid et al., 2001; Baka et al., 2011; Simion et al., 2014).

These cultures are composed mainly of Lactobacillus spp. and Staphylococcus spp., which have the capacity for improving sensorial and textural characteristics such as colour, flavour, taste, hardness, and cohesiveness, among others. Strains of these genera are used for inoculating minced-meat portions for sausage production in numbers varying from $10^{5}$ to $10^{8}$ cells of microorganisms per gram of meat. Yeasts and moulds are also used to improve sausage sensory quality, and the latter, due to their aerobic metabolism, are applied to the sausage skin or casing.

Texture profile analysis (TPA) is commonly used as an instrumental method of uni-axial compression and consists of compressing food material twice and quantifying the mechanical parameters using force-deformation 
curves for food products (Szczesniak et al., 1963; Bourne, 1978; Foegedinga et al., 2003). According to Szczesniak (2002), one of the most important advantages of the use of this method is that it produces high correlations between some instrumental parameters and sensory ratings. Honikel (1997) tried to standardize methods for measuring meat texture, and strongly recommended the use of sensory evaluation in order to validate instrumental methods for determining tenderness. In a study examining fermented sausages by Herrero et al. (2007), TPA and physico-chemical measurements were performed, as well as a breaking strength by tensile test. The results obtained allowed these meat products to be grouped according to four different textural profiles. Yang et al. (2007) examined new preparation formulas for low-fat sausages with three different levels of added hydrated oatmeal and tofu. The aim of the study was to determine the effects of the type and level of texture-modifying agents on the physical and sensory properties of low-fat sausages. Rubio et al. (2007) carried out research on "salsichon" with high unsaturated fat content, vacuum packed under modified atmospheric conditions, analysing its microbiological, physico-chemical and sensory properties in order to evaluate quality changes during refrigeration storage. TPA was performed and the parameters determined from the force-time curves obtained were hardness, springiness, cohesiveness and chewiness. Wang et al. (2009) also performed TPA to determine the effects of phosphate level on water-holding capacity and texture of emulsion-type sausages during storage. Spaziani et al. (2009) examined low-acid sausages in order to characterize their physico-chemical, microbiological, and textural properties during ripening, also performing TPA; once again the parameters determined were: hardness, cohesiveness and adhesiveness. In the light of the results of all this previous research, TPA tests were used in the present study in order to identify differences in texture parameters, mainly in order to corroborate the sensory analysis results of previous studies.

Polycyclic aromatic hydrocarbons (PAHs) are organic compounds formed by the incomplete combustion of organic matter, environmental pollutants originating from countless natural processes and human activities. Contamination by PAHs deriving from intense thermal processes due to the direct deposition of PAHs from smoke occurs as a result of the incomplete combustion of different thermal agents. Because many of these are highly suspect as aetiological agents in human cancer, the chemical analysis of PAHs is of great environmental and toxicological importance (Lorenzo et al., 2011; Courter et al., 2008; Lin et al., 2008; Park et al., 2008). Among PAHs, benzo[a]pyrene (BaP) is used as a marker for the occurrence of carcinogenic PAHs (Lorenzo et al., 2011). In Europe, maximum tolerance levels for $\mathrm{BaP}$ in smoke condensates have been established (Commission Regulation EC no. 2065/2003) and are applied to several foodstuffs categories (EC n ${ }^{\circ} 1881 / 2006$ ). However, recent data has shown that $\mathrm{BaP}$ alone cannot be considered as a satisfactory indicator of PAHs occurrence in foods (EFSA, 2008). As a result, a new regulation (EC ${ }^{\circ}$ 835/2011) was introduced in September 2012 and provides for PAH4 marker contents, composed of $\mathrm{BaP}$, benzo(a)anthracene $(\mathrm{BaA})$, chrysene (CHR) and benzo(b)fluoranthene (BbFA), to be set at $30 \mu \mathrm{g} \mathrm{kg}^{-1}$ (EC, 2011). According to the European Food Safety Authority (EFSA, 2008), meat and meat products are one of the food categories contributing most to the dietary PAHs intake per day of European Union member state consumers. This demonstrates the important role of PAHs studies for all smoked food products, with a view to quantifying these compounds and identifying the factors which affect amounts occurring.

PAHs biodegradation depends on the nature and the chemical structure of the compound being degraded, environmental conditions, and the number and type of microorganisms involved. These compounds are biodegraded/biotransformed into less complex metabolites, and by means of mineralization into inorganic minerals: $\mathrm{H}_{2} \mathrm{O}$ and $\mathrm{CO}_{2}$, in aerobiosis, or $\mathrm{CH}_{4}$ in anaerobiosis. The rate of biodegradation depends on several factors, such as chemical structure, their chemical portioning in the medium and their cellular transporting properties, besides environmental factors such as $\mathrm{pH}$, temperature, oxygen availability, degree of acclimation, the availability of nutrients and the microbial population (Roseiro et al., 2010). A number of bacterial species are known to degrade PAHs and most of them are isolated from contaminated soil or sediments. Alcaligenes spp., Enterobacter spp., Haemophilus spp., Pseudomonas aeruginosa, P. fluorescens, Sphingomonas spp., Neptunomonas spp., Rhodococcus spp., Bacillus spp., Paenibacillus spp., and Mycobacteria spp. are some commonly studied bacteria. Also ligninolytic fungi have the capacity to degrade PAH. Phanerochaete chrysosporium, Bjerkandera adusta, and Pleurotus ostreatus are common PAH-degrading fungi (Kanaly \& Harayama, 2000; Tian et al., 2008; Haritash \& Kaushik, 2009; Arulazhagan \& Vasudevan, 2011; Wang et al., 2012). Despite the fact that these microorganisms are used in soil or water decontamination, few studies relate PAHs degradation to Lactobacillus acidophilus (Wang et al., 2012) and Staphylococcus warneri (Moscoso, 2012). This enables the hypothesis to be formulated that some starters used in food production have the capacity for reducing PAHs.

A number of studies of "Paio do Alentejo" have been carried out in order to characterize this type of product, 
which is known by a number of different names, in accordance with the region of origin of production (Elias et al., 2000; Elias et al., 2003; Roseiro et al., 2008; Roseiro et al., 2010; Elias \& Carrascosa, 2010; Elias et al., 2011).

The main aim of this paper is to evaluate the effect of two starter cultures: a commercial starter culture, which has been previously tested by starter producer, and an experimental starter culture. Authors intent to evaluate the effect of both starter cultures on the sensory and textural properties and PAH levels of "Paio do Alentejo".

\section{Materials and Methods}

\subsection{Sausage Technology and Sampling Procedures}

"Paio do Alentejo", a Portuguese traditional cured sausage, is cylindrical shaped, with a diameter of 4 to $5 \mathrm{~cm}$ and a length of 25 to $30 \mathrm{~cm}$. It is made with meat from the Alentejano pig breed, known for its high intra- and inter-muscular fat content. "Paio do Alentejo" was prepared at a traditional factory located in Alentejo region.

The production process involves mechanically mincing meat previously cut into cubes measuring approximately $2.5 \mathrm{~cm}$ and mixed with red pepper (Capsicum annuum L.) paste (6\%), water $(3 \%)$, garlic (Allium sativum L.) paste $(1 \%)$, salt $(0.7 \%)$, disodium diphosphate $(0.03 \%)$, pentasodium triphosphate $(0.03 \%), \mathrm{NaNO}_{3}(0.03 \%)$, $\mathrm{KNO}_{3}(0.008 \%)$ and $\mathrm{KNO}_{2}(0.007 \%)$. Red pepper and garlic pastes contain $17 \%$ of salt $(\mathrm{NaCl})$.

One batch (S1) was inoculated with a commercial starter (TEXEL ${ }^{\circledR}$ ELSE BR) in accordance with the instructions of the starter producer, containing Lactobacillus spp., Micrococcaceae and yeasts; another batch (S2) was inoculated with an experimental starter containing Lactobacillus sakei $\left(10^{5} \mathrm{cells} / \mathrm{g}\right)$ and Staphylococcus xylosus $\left(10^{5}\right.$ cells $\left./ \mathrm{g}\right)$; a third batch $(\mathrm{C})$, the control batch, was not inoculated.

The mixture of meat and other ingredients was stored under controlled conditions at $5{ }^{\circ} \mathrm{C}$ and $90 \%$ of relative humidity for 72 hours for ripening purposes. Then the meat was stuffed into natural casings made from the large intestines of pigs, measuring $50-55 \mathrm{~mm}$ in diameter.

The drying operation occurs in two phases: sausages are dried (1) in a smoking room (connecting directly with the exterior by chimney) for 48 hours [at a temperature of $18-24{ }^{\circ} \mathrm{C}$ and a relative humidity of $30-60 \%$, with smoke generated by burning oak wood (Quercus ilex, L.)], (2) in special chambers under controlled conditions for 40 days (at a temperature of $9{ }^{\circ} \mathrm{C}$ and a relative humidity of $80-85 \%$ ). After processing, sausages were used immediately for sensory, TPA, $\mathrm{pH}$ and $\mathrm{a}_{\mathrm{w}}$ analysis, vacuum packed and stored deep frozen $\left(-80^{\circ} \mathrm{C}\right)$ until $\mathrm{PAH}$ analysis was carried out.

The sensory and textural properties (Texture Profile Analysis) of five samples from each different batch of (S1, $\mathrm{S} 2$ and $\mathrm{C}$ ) were evaluated, while $\mathrm{pH}$ and $\mathrm{a}_{\mathrm{w}}$ levels were also determined and PAHs quantified.

\subsection{Sensory Evaluation}

A panel of 12 qualified judges evaluated five sausage samples per batch. Sensory evaluation was carried out in a special room in accordance with the method described by Costell and Durán (1981 a, b, c, d). Whole sausages were cut into slices ( $3 \mathrm{~mm}$ thick) 30 minutes before analysis. A sample of five sausages per session was presented in random order. Three slices from each dry cured sausage were presented on small white plates denoted with a three-digit random number. A descriptive quantitative method was adopted, using a structured scale ranging from 0 (no sensation perceived) to 100 (maximum sensation perceived). The following attributes were considered: colour intensity, off colour, aroma intensity, off aroma, tenderness, succulence, flavour intensity, off flavour, salt perception and overall acceptability. For salt perception, the optimum value considered was 50 (values below 50 indicate low salt content while values above 50 indicate a high salt content). Judges rinsed their mouths out with neutral water and ate a cracker during samples evaluation.

\subsection{Texture Profile Analysis}

Texture Profile Analysis (TPA) using a cylindrical flat-ended plunger (with a diameter of $1.13 \mathrm{~cm}$ and an area of 1 $\mathrm{cm}^{2}$ ) was performed using a Stable Micro System TA-Hdi (Stable Micro Systems, Godalming, England) in accordance with the methodology described by Honikel (1997), Caine et al. (2003) and Martinez et al. (2004). Tests were carried out at room temperature $\left(20^{\circ} \mathrm{C} \pm 1{ }^{\circ} \mathrm{C}\right)$. The samples were previously cut into slices $1 \mathrm{~cm}$ thick, providing circular samples with a 4 to $5 \mathrm{~cm}$ diameter, which were compressed twice in two consecutive cycles of $50 \%$ compression with $5 \mathrm{~s}$ intervals between cycles, while the plunger was actioned at a constant speed of $1 \mathrm{~mm} / \mathrm{s}$. Force/time curves were obtained in order to calculate the following parameters: hardness, adhesiveness, springiness, cohesiveness, gumminess, resilience, and chewiness. 


\section{$2.4 \mathrm{pH}$ and $a_{w}$}

After removing the sausage casings, $\mathrm{pH}$ was determined in accordance with Norma Portuguesa NP - 3441 (1990) using a pH-meter (Crison 507, Barcelona, Spain). Regarding water activity $\left(\mathrm{a}_{\mathrm{w}}\right)$, measurements were carried out using a hygrometer (Hygroskop Rotronic DT, Zurich, Switzerland) with a WA-40 probe at $25^{\circ} \mathrm{C}$.

\subsection{Polycyclic Aromatic Hydrocarbons Profile (PAHs)}

\subsubsection{Standards and Reagents}

For calibrations a standard mixture of 16 PAHs EPA 610 Polynuclear Aromatic Hydrocarbons Mix produced by Supelco (Bellefonte, PA, USA) was used. Potassium hydroxide, methanol and n-hexane (analytical grade), and acetonitrile (HPLC-grade) were obtained from Panreac (Barcelona, Spain). Ultrapure water was obtained from a Millipore Milli-Q water purification system.

\subsubsection{PAH Extraction}

As regards the casing and the sausage meat/fat mixture, PAH extraction was performed in accordance with indications provided by Santos et al. (2011). Samples were homogenized in a Grindomix (GM 200 Retsch, Haan, Germany) and $10 \mathrm{~g}$ was saponified under reflux in the presence of a mixture of potassium hydroxide, water and methanol. Saponified extract was diluted in $100 \mathrm{ml}$ of a mixture of methanol and water $(80: 20, \mathrm{v} / \mathrm{v})$ and extracted with $50 \mathrm{ml}$ of n-hexane, 4 times. The resulting fractions containing PAHs were combined and evaporated to dryness in a rotatory evaporator (Laborota 4001, Heidolph, Schwabach, Germany) under reduced pressure. The final residue was dissolved in $3 \mathrm{ml}$ of acetonitrile, filtered through a $0.45 \mu \mathrm{m}$ membrane $(25 \mathrm{~mm}$ GHP, Acrodisc, Waters, Milford, MA) and an aliquot $(20 \mu \mathrm{l})$ injected into a chromatographic system for quantification.

\subsubsection{HPLC/UV-FLD Analysis}

Chromatographic separation of the 16 PAHs (acenaphthylene - ACL, naphthalene - NA, acenaphthene - AC, fluorene - FL, phenanthrene - PHE, anthracene - AN, fluoranthene - FA, pyrene - PY, benzo $[a]$ anthracene $\mathrm{BaA}$, chrysene - CHR, benzo[b]fluoranthene - BbFA, benzo[k]fluoranthene - BkFA, benzo[a]pyrene - BaP, dibenzo[ $a, h]$ anthracene - DbahA, benzo[ghi]perylene - BghiP, indeno[1,2,3- $c d]$ pyrene - IP) was carried out in accordance with indications provided by Santos et al. (2011).

Limits of detection (LOD), quantification (LOQ) and recovery were described by Gomes et al. (2013). The sum of the final PAH content in samples was regarded as total PAH content of the whole product.

\subsection{Statistical Analysis}

For the purpose of statistical data processing, an ANOVA was performed, using the Statistica 5.1 program, and means were compared using the HSD Tukey test. Principal Components Analysis (PCA) was also used.

\section{Results}

\subsection{Sensory Analysis}

ANOVA for sensory results evidenced no significant differences for any attribute $(p>0.05)$. Overall acceptability values were very similar for sausages from the three batches while the highest value was recorded for Batch C (Table 1). In this batch, colour intensity, aroma intensity and flavour intensity were the lowest out of the three batches, suggesting that the panellists showed a preference for a rather bland product. The use of starter cultures in sausages to improve colour, aroma and flavours intensities is widespread, and while this is widely recognized it was not appreciated by the panellists, probably due to the high quality of "Paio Alentejano" produced for this research. Batch S2 produced the lowest overall acceptability but highest scores for aroma intensity, succulence and salt perception. The production of some microorganism metabolites, among them lactic acid bacteria, may provide an unusual flavour; however, this is not the same as off flavour. 
Table 1. Arithmetic Mean values (from 0 to 100) and Standard Deviation for sensory variables for different batches: C (control), S1 (commercial starter culture) and S2 (experimental starter culture)

\begin{tabular}{|c|c|c|c|c|c|c|c|c|c|c|}
\hline Batch & $\begin{array}{l}\text { Colour } \\
\text { intensity }\end{array}$ & $\begin{array}{l}\text { Off } \\
\text { Colour }\end{array}$ & $\begin{array}{l}\text { Aroma } \\
\text { intensity }\end{array}$ & $\begin{array}{l}\text { Off } \\
\text { Aroma }\end{array}$ & Tenderness & Succulence & $\begin{array}{l}\text { Flavour } \\
\text { intensity }\end{array}$ & $\begin{array}{l}\text { Off } \\
\text { Flavour }\end{array}$ & $\begin{array}{l}\text { Salt } \\
\text { Perception }\end{array}$ & $\begin{array}{l}\text { Overall } \\
\text { Acceptability }\end{array}$ \\
\hline \multirow{2}{*}{$\mathrm{C}$} & 66.8 & \multirow{2}{*}{0.0} & 69.7 & \multirow{2}{*}{0.0} & 55.4 & 68.6 & 72.4 & \multirow{2}{*}{0.0} & 56.1 & 73.2 \\
\hline & \pm 12.2 & & \pm 10.0 & & \pm 8.8 & \pm 8.0 & \pm 9.2 & & \pm 10.7 & \pm 7.2 \\
\hline \multirow{2}{*}{ S1 } & 71.1 & \multirow{2}{*}{0.0} & 71.0 & \multirow{2}{*}{0.0} & 54.1 & 67.1 & 73.5 & \multirow{2}{*}{0.0} & 58.1 & 72.9 \\
\hline & \pm 14.1 & & \pm 11.2 & & \pm 5.2 & \pm 9.9 & \pm 9.9 & & \pm 9.7 & \pm 10.4 \\
\hline \multirow{2}{*}{$\mathrm{S} 2$} & 69.9 & \multirow{2}{*}{0.0} & 72.0 & \multirow{2}{*}{0.0} & 51.4 & 71.9 & 73.1 & \multirow{2}{*}{0.0} & 59.7 & 71.8 \\
\hline & \pm 15.0 & & \pm 11.4 & & \pm 8.4 & \pm 8.5 & \pm 10.1 & & \pm 10.8 & \pm 10.6 \\
\hline F value & 0.695 & & 0.185 & & 1.864 & 0.685 & 0.085 & & 0.818 & 0.151 \\
\hline $\mathrm{p}$ value & 0.502 & & 0.832 & & 0.162 & 0.507 & 0.919 & & 0.445 & 0.860 \\
\hline
\end{tabular}

\subsection{TPA}

Both the scores awarded by the panellists and instrumental measurements were very similar for three batches (S1, S2 and C).

In accordance with ANOVA for TPA results, the only significant difference was obtained for cohesiveness $(\mathrm{p}<$ 0.05), which was higher for Batches S1 and S2 as compared with Batch C (Table 2). Here, starter cultures contributed towards an increase in the linking forces between meat portions in inoculated sausages. From a practical point of view, this is an extremely important feature, which could justify the use of starters, even with high-quality products. Besides this, these sausages produced with starters were more tender (hardness $41.34 \mathrm{~N}$ and $41.99 \mathrm{~N})$ than those of control batch $(45.07 \mathrm{~N})$. The results obtained for both inoculated batches were generally very similar, despite their different composition: a commercial starter and an experimental starter, which has not yet been used for commercial purposes.

Table 2. Arithmetic Mean values and Standard Deviation for TPA variables for different batches: C (control), S1 (commercial starter culture) and S2 (experimental starter culture)

\begin{tabular}{|c|c|c|c|c|c|c|c|}
\hline Batch & $\begin{array}{l}\text { Hardness } \\
\text { (N) }\end{array}$ & $\begin{array}{l}\text { Adhesiveness } \\
(\mathrm{N} \times \mathrm{s})\end{array}$ & $\begin{array}{l}\text { Springiness } \\
(\mathrm{mm})\end{array}$ & Cohesiveness & Gumminess $(\mathrm{N})$ & Resilience & $\begin{array}{l}\text { Chewiness } \\
(\mathrm{N} \times \mathrm{mm})\end{array}$ \\
\hline \multirow[t]{2}{*}{$\mathrm{C}$} & 45.07 & -2.61 & 0.85 & $4.31^{\mathrm{b}}$ & 28.59 & 0.17 & 24.58 \\
\hline & \pm 12.27 & \pm 1.10 & \pm 0.06 & \pm 0.45 & \pm 8.02 & \pm 0.03 & \pm 7.84 \\
\hline \multirow[t]{2}{*}{ S1 } & 41.34 & -3.46 & 0.88 & $4.75^{\mathrm{a}}$ & 26.59 & 0.16 & 23.47 \\
\hline & \pm 8.59 & \pm 1.09 & \pm 0.07 & \pm 0.34 & \pm 4.96 & \pm 0.02 & \pm 5.06 \\
\hline \multirow[t]{2}{*}{$\mathrm{S} 2$} & 41.99 & -3.24 & 0.84 & $4.63^{\mathrm{a}}$ & 26.41 & 0.16 & 22.26 \\
\hline & \pm 12.96 & \pm 1.39 & \pm 0.06 & \pm 0.54 & \pm 6.85 & \pm 0.03 & \pm 6.52 \\
\hline F value & 0.455 & 2.018 & 1.832 & 3.748 & 0.484 & 1.736 & 0.467 \\
\hline $\mathrm{p}$ value & 0.637 & 0.146 & 0.173 & 0.032 & 0.620 & 0.189 & 0.630 \\
\hline
\end{tabular}

Within the same parameter (column), means with a different superscript are significantly different $(p<0.05)$.

Onega et al. (2001) in a study of raw and cooked meat also found that hardness, springiness and chewiness obtained by means of TPA tests showed a high degree of correlation with sensory parameters.

Sometimes this degree of coherence has not been evident, such as in the study carried out by Caceres et al. (2006), who reported that although statistical analysis showed significant differences, changes are not reflected in sensory analysis for batches of sausages with different fat levels and different amounts of added calcium.

With regard to PCA analysis (see Figure 1 and Table 3), Factor 1 accounted for $31 \%$ of the variance of variables and established the association between succulence, deriving from sensory evaluation, and adhesiveness, 
obtained from TPA, both of which are shown on one side of the Factor 1 axis and show a positive factor-variable correlation (see Table 4). This may be related to a high degree of attractiveness of the surface or skin of "Paio do Alentejo" and the consequent positive effect on the judges' palate and teeth, which may be reflected in a high level of saliva production which thus may lead to the high scores recorded for succulence. Factor 2 accounted for $20 \%$ of results, and cohesiveness deriving from TPA is related to succulence deriving from sensory evaluation. Once more, succulence, as evaluated by the judges, correlates positively with a textural parameter. PCA projection of variables revealed the very close relationship between hardness, as evaluated by the panellists, on the one hand, and TPA on the other hand, which are both located in the same quadrant; this may provide an indication of the excellence of the performance of the panel, being able to distinguish even small changes in hardness. Ruiz de Huidobro et al. (2005) also found that with regard to sensory properties such as hardness, TPA was a better predictor than other instrumental methods.

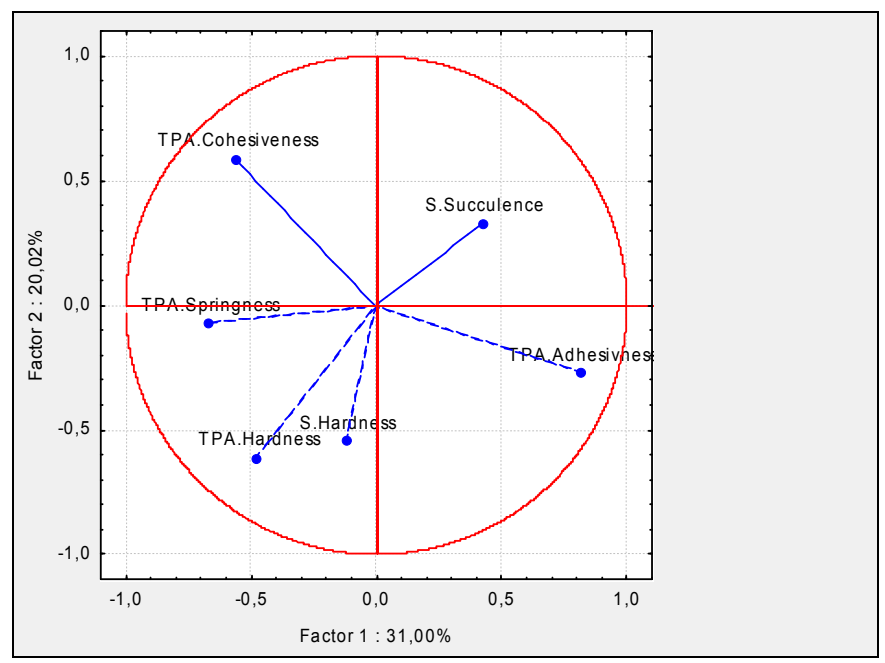

Figure 1. Principal Component Analysis. Projection of variables on the factor plane, considering 2 factors

Table 3. Principal Component Analysis. Eigenvalues of correlation matrix and related statistics

\begin{tabular}{ccc}
\hline Factor & Eigenvalue & $\%$ Total \\
\hline 1 & 1.860 & 31.004 \\
2 & 1.201 & 20.020 \\
3 & 1.036 & 17.269 \\
4 & 0.931 & 15.518 \\
5 & 0.553 & 9.223 \\
6 & 0.418 & 6.966 \\
\hline
\end{tabular}

Table 4. Principal Component Analysis. Factor-variable correlations (factor loadings), based on correlations

\begin{tabular}{cccc}
\hline & Factor 1 & Factor 2 & Factor 3 \\
\hline Sensory Hardness & -0.124 & -0.543 & 0.560 \\
Sensory Succulence & 0.425 & 0.330 & -0.520 \\
TPA Hardness & -0.478 & -0.613 & -0.411 \\
TPA Adhesiveness & 0.812 & -0.270 & 0.145 \\
TPA Springiness & -0.676 & -0.073 & -0.307 \\
TPA Cohesiveness & -0.565 & 0.586 & 0.410 \\
\hline
\end{tabular}

Hardness, chewiness and springiness are extremely useful parameters for the assessment of meat texture (Ruiz 
de Huidobro et al., 2001). González-Fernández et al. (2006) prepared four batches of Spanish chorizo; one was a control batch while the other three batches were inoculated with L. sakei K29, Pediococcus sp. P22 and Pediococcus sp. P208, respectively; the textural parameters examined were hardness, springiness, cohesiveness and chewiness, and for all parameters the lowest value was that of the control batch. Similar results were obtained by Marcos et al. (2007) for Spanish fuet (Spanish thin cured-dry pork sausage) and chorizo. With the exception of cohesiveness, the results of the present study are different, as hardness and chewiness were higher for Batch $\mathrm{C}$ than Batches S1 and S2; in addition, springiness for Batch $\mathrm{C}$ was similar to that of Batch S2 but lower than that of Batch S1 (see Table 2).

\section{$3.3 \mathrm{pH}$ and $a_{w}$}

The results of an analysis of variance of $\mathrm{pH}$ and $\mathrm{a}_{\mathrm{w}}$ values do not show significant differences between batches, while mean values for these variables are very similar (see Table 5). In fact, the use of the two starter cultures did not influence either $\mathrm{pH}$ or $\mathrm{a}_{\mathrm{w}}$. $\mathrm{pH}$ mean varied from 5.23 (Batch C) to 5.26 (Batch S2), while $\mathrm{a}_{\mathrm{w}}$ ranged from 0.881 (Batch S1) to 0.884 (Batches C and S2). Once again, the use of the two starters did not appear to have any influence on the characteristics of "Paio do Alentejo". Elias and Carrascosa (2010) studied "Paio do Alentejo" produced at two manufacturing plants and obtained a $\mathrm{pH}$ mean value of 5.45 and an $\mathrm{a}_{\mathrm{w}}$ mean value of 0.821 for non-smoked products, and a $\mathrm{pH}$ mean value of 5.74 and an $\mathrm{a}_{\mathrm{w}}$ mean value of 0.818 for smoked products. These values are comparable with those obtained in the present study as lower $a_{w}$ values reflect a greater degree of curing, while the relatively higher $\mathrm{pH}$ values recorded by Elias and Carrascosa (2010) may result from proteolytic reactions occurring in the final stage of curing. Similar $\mathrm{pH}$ and $\mathrm{a}_{\mathrm{w}}$ values for "Paio do Alentejo" in the present study were comparable with those recorded by Elias et al. (2011) and Elias and Carrascosa (2013).

Table 5. Arithmetic Mean values and Standard Deviation for $\mathrm{pH}$ and $\mathrm{a}_{\mathrm{w}}$ variables for different batches: C (control), S1 (commercial starter culture) and S2 (experimental starter culture)

\begin{tabular}{ccc}
\hline Batch & $\mathrm{pH}$ & $\mathrm{a}_{\mathrm{w}}$ \\
\hline $\mathrm{C}$ & 5.23 & 0.884 \\
& \pm 0.05 & \pm 0.008 \\
$\mathrm{~S} 1$ & 5.25 & 0.881 \\
& \pm 0.10 & \pm 0.018 \\
$\mathrm{~S} 2$ & 5.26 & 0.884 \\
& \pm 0.08 & \pm 0.021 \\
F value & 1.912 & 1.748 \\
p value & 0.161 & 0.187 \\
\hline
\end{tabular}

\subsection{PAH}

Regarding the PAH analysis of variance of the results of the present study, no significant differences were found for any PAH $(p>0.05)$ for the three inoculation types. In accordance with ANOVA, arithmetic mean values for PAHs detected for the three batches are statistically comparable (see Table 6). Nevertheless, Batch S1 showed the lowest concentrations with regard to the majority of PAHs. Total PAHs, Light PAH, Heavy PAH and PAH4 levels were also lower for Batch S1.

Light PAHs include ACL, NA, AC, FL, PHE, FA, PY, BaA and CHR, while Heavy PAHs include BbFA, BaP, BkFA, DbahA, BghiP, IP, and PAH4 includes ACL, NA, BbFA and BaP.

The prevalence of Light PAHs over heavy compounds for different smoked meat products has been reported on several occasions by different authors (Ciecierska \& Obiedziński, 2007; Djinovic et al., 2008; Stumpe-Vīksna et al., 2008; Roseiro et al., 2011; Santos et al., 2011). However, the concentration of each is variable.

The five major compounds found in the present study are AC, FL, PHE, NA and ACL; they are light PAHs with 2 or 3 aromatic rings, representing more than $83 \%$ of total PAHs. The results of this study agree with those obtained by Gomes et al. (2013). The total amount of heavy PAHs accounts for $0.65 \%$ of total PAHs (Batch C), being the lowest value recorded, and $0.72 \%$ (Batch $\mathrm{S} 1$ ), the highest value recorded. The highest concentration of heavy PAHs was $2.03 \mu \mathrm{g} \mathrm{kg}^{-1}$ (DbahA, Batch S2) and the lowest concentration was $0.66 \mu \mathrm{g} \mathrm{kg}^{-1}$ (BkFA, Batch $\mathrm{S} 1$ ), while concentrations of each heavy PAH for each batch were very similar. BaP levels were $1.00 \mathrm{~g} \mathrm{~kg}^{-1}$ 
(Batch S1), $1.03 \mu \mathrm{g} \mathrm{kg}^{-1}$ (Batch C) and $1.06 \mu \mathrm{g} \mathrm{kg}^{-1}$ (Batch S2). The lowest value recorded for PAH4 was 48.80 $\mu \mathrm{g} \mathrm{kg}^{-1}$ (Batch S1) and the highest was $55.64 \mu \mathrm{g} \mathrm{kg}^{-1}$ (Batch C). These values were higher than those obtained by Gomes et al. (2013) for one type of Portuguese traditional sausage. These authors obtained values ranging from 4.21 to $10.35 \mu \mathrm{g} \mathrm{kg}^{-1}$ and the main contributors to this were BaA and CHR, both light compounds, as is the case with the present study. While the results reported by Gomes et al. (2013) were obtained using sausages without casings, in the present study samples were made up of products both with and without casings, which accounts for high PAHs levels (Roseiro et al., 2011; Santos et al., 2011). According to EFSA (2008), even if the casings of "Paio do Alentejo" are consumed (which does not normally occur), PAHs levels represent an irrelevant hazard.

Table 6. Arithmetic Mean values for the PAH content $\left(\mu \mathrm{g} \mathrm{kg}^{-1}\right)$ for the different batches: C (control), S1 (commercial starter culture) and S2 (experimental starter culture)

\begin{tabular}{|c|c|c|c|c|c|}
\hline Bath & $\mathrm{C}$ & S1 & S2 & $\mathrm{F}$ value & $\mathrm{p}$ value \\
\hline ACL & 91.55 & 81.86 & 78.75 & 0.174 & 0.844 \\
\hline NA & 178.57 & 128.89 & 182.07 & 0.720 & 0.524 \\
\hline $\mathrm{AC}$ & 220.97 & 200.09 & 216.73 & 0.160 & 0.856 \\
\hline FL & 204.21 & 173.01 & 213.47 & 0.359 & 0.713 \\
\hline PHE & 186.32 & 184.27 & 200.51 & 0.059 & 0.943 \\
\hline AN & 57.68 & 39.05 & 51.84 & 1.158 & 0.376 \\
\hline FA & 29.45 & 33.60 & 30.97 & 0.062 & 0.941 \\
\hline PY & 26.14 & 24.74 & 24.32 & 0.030 & 0.970 \\
\hline $\mathrm{BaA}$ & 23.94 & 21.44 & 25.58 & 0.187 & 0.834 \\
\hline CHR & 29.27 & 25.09 & 23.08 & 0.315 & 0.741 \\
\hline BbFA & 1.40 & 1.27 & 1.50 & 0.240 & 0.794 \\
\hline $\mathrm{BaP}$ & 1.03 & 1.00 & 1.06 & 0.054 & 0.948 \\
\hline $\mathrm{BkFA}$ & 0.67 & 0.66 & 0.75 & 0.238 & 0.795 \\
\hline DBahA & 1.88 & 1.87 & 2.03 & 0.335 & 0.728 \\
\hline BghiP & 1.86 & 1.80 & 1.95 & 0.449 & 0.658 \\
\hline IP & N.D. & N.D. & N.D. & & \\
\hline $\mathrm{PAH} 4^{\mathrm{A}}$ & 55.64 & 48.80 & 51.22 & 0.173 & 0.845 \\
\hline Light PAHs ${ }^{\mathrm{B}}$ & 827.12 & 711.95 & 830.59 & 0.287 & 0.761 \\
\hline Heavy PAHs ${ }^{\mathrm{C}}$ & 6.84 & 6.60 & 7.29 & 0.272 & 0.771 \\
\hline Total PAHs & 1054.93 & 918.64 & 1054.61 & 0.270 & 0.772 \\
\hline
\end{tabular}

N.D. - not detected.; ${ }^{\mathrm{A}} \mathrm{PAH} 4$ content was determined by adding BaA, CHR, BbFA and BaP. ${ }^{\mathrm{B}}$ Light PAH $\mathrm{s}$ content was determined by adding ACL, NA, AC, FL, PHE, AN, FA, PY, BaA and CHR. ${ }^{C}$ Heavy PAHs content was determined by adding BbFA, BkFA, BaP, DBahA, BghiP and IP.

Despite the lack of significant differences between batches for all PAHs, samples inoculated with starter S1 show lower PAH values, except for ACL and FA (see Table 6). These results may be related to the benefit of the use of starter $\mathrm{S} 1$ in order to decrease $\mathrm{PAH}$ production.

\section{Conclusions}

The addition of starters to "Paio do Alentejo" produced no significant improvement in sensory or rheological properties (except for cohesiveness), or PAH levels.

Total values for PAHs, PAH4, light PAHs and heavy PAHs were smaller than those recorded in other studies of traditional Portuguese sausages (Roseiro et al., 2011; Santos et al., 2011). This is due to the relatively small duration of exposure to smoke (48 hours) to which such products are subject. However, considering the fact that 
the manufacturing process for the sausages examined in the present study involved stuffing meat in natural casings with a high fat content, the casing accounts for the majority of PAH values. Because casings are not usually consumed, real PAH values in terms of human consumption are lower than those reported in the present paper.

In this study, no differences were found between the three batches. This may be accounted by the presence of interesting technological microorganisms, such as lactic acid bacteria and Micrococcaceae, in the usual house flora. Usually, such flora is well adapted to the environmental conditions of the respective habitat and, for this reason, assumes a dominant role, thus reducing the impact of added microorganisms.

The lack of positive effects noted with regard to such starters is probably due to the high quality of "Paio do Alentejo" produced at the meat manufacturing plant, which is evident even without the use of starters: it should be noted that all batches received high scores from the panellists.

Starter cultures were initially developed and used for improving the food safety of meat products, by their presence, avoiding pathogens growth, and producing metabolites such organic acids, or bacteriocins, among others. Later, they were used for enhancing other aspects of quality such as sensory, textural and technological characteristics. Thus, any advantages of using starter cultures with products characterised by a very high level of quality are not immediately evident. Nevertheless, the use of starter cultures with such products may be recommended in order to combat the possible negative impacts of unforeseeable technological problems, thus providing an additional guarantee of the quality of final products.

\section{Acknowledgements}

This work was funded by the PRODER Project, Medida 4.1/2009 ( ${ }^{\circ}$ 13.021), and by FEDER Funds through the Operational Programme for Competitiveness Factors - COMPETE and National Funds through FCT Foundation for Science and Technology - under the Strategic Project Pest-C/AGR/UI0115/2011. Authors also wishes thank to PALADARES ALENTEJANOS, Lda. for sausage production.

\section{References}

Andrade, M. J., Córdoba, J. J., Casado, E. M., Córdoba, M. G., \& Rodríguez, M. (2010). Effect of selected strains of Debaryomyces hansenii on the volatile compound production of dry fermented sausage "salchichón". Meat Science, 85(2), 256-264. http://dx.doi.org/10.1016/j.meatsci.2010.01.009

Arulazhagan, P., \& Vasudevan, N. (2011). Biodegradation of polycyclic aromatic hydrocarbons by a halotolerant bacterial strain Ochrobactrum sp. VA1. Marine Pollution Bulletin, 62(2), 388-394. http://dx.doi.org/10.1016/j.marpolbul.2010.09.020

Baka, A. M., Papavergou, E. J., Pragalaki, T., Bloukas, J. G., \& Kotzekidou, P. (2011). Effect of selected autochthonous starter cultures on processing and quality characteristics of Greek fermented sausages. $L W T$ and Food Science and Technology, 44(1), 54-61. http://dx.doi.org/10.1016/j.lwt.2010.05.019

Benito, M. J., Martín, A., Aranda, E., Pérez-Nevado, F., Ruiz-Moyano, S., \& Córdoba, M. G. (2007). Characterization and selection of autochthonous lactic acid bacteria isolated from traditional Iberian dry-fermented Salchichón and Chorizo sausages. Journal of Food Science, 72, 193-201. http://dx.doi.org/10.1111/j.1750-3841.2007.00419.x

Bourne, M. C. (1978). Texture profile analysis. Food Technology, 32(7), 62-66, 72.

Bover-Cid, S., Izquierdo-Pulido, M., \& Vidal-Carou, M. C. (1999). Effect of proteolytic starter cultures of Staphylococcus spp. on biogenic amine formation during the ripening of dry fermented sausages. $\begin{array}{lllll}\text { International Journal of Food } & \text { Microbiology, } & 46(2), & \text { 95-104. }\end{array}$ http://dx.doi.org/10.1016/S0168-1605(98)00170-6

Bover-Cid, S., Izquierdo-Pulido, M., \& Vidal-Carou, M. C. (2001). Effectiveness of Lactobacillus sakei starter culture in the reduction of biogenic amine accumulation as a function of the raw material quality. Journal of Food Protection, 64(3), 367-373.

Cáceres, E., García, M. L., \& Selgas, M. D. (2006). Design of a new cooked meat sausage enriched with calcium. Meat Science, 73(2), 368-377. http://dx.doi.org/10.1016/j.meatsci.2005.12.016

Caine, W. R., Aalhus, J. L., Best, D. R., Dugan, M. E. R., \& Jeremiah, L. E. (2003). Relationship of texture profile analysis and Warne-Bratzler shear force with sensory characteristics of beef rib steaks. Meat Science, 64(4), 333-339.

Ciecierska, M., \& Obiedzinski, M. W. (2007). Influence of smoking process on polycyclic aromatic hydrocarbons' content in meat products. Acta Sci. Poli Technol. Aliment, 6, 17-28. 
Costell, E., \& Durán, L. (1981a). El análisis sensorial en el control de calidad de los alimentos. I - Introduccion. Rev. Agroquim. Tecnol. Alim., 21(1), 1-10.

Costell, E., \& Durán, L. (1981b). El análisis sensorial en el control de calidad de los alimentos. II Planteamiento y planificación: selección de pruebas. Rev. Agroquim. Tecnol. Alim., 21(2), 149-166.

Costell, E., \& Durán, L. (1981c). El análisis sensorial en el control de calidad de los alimentos. III - Planificacion, selección de jueces y diseño estatistico. Rev. Agroquim. Tecnol. Alim., 21(4), 455-470.

Costell, E., \& Durán, L. (1981d). El análisis sensorial en el control de calidad de los alimentos. IV- Realización y análisis de los datos. Rev. Agroquim. Tecnol. Alim., 22(1), 10-21.

Courter, L. A., Luch, A., Tamara, M. J., Arlt, V. M., Fischer, K., \& Bildfell, R. (2008). The influence of diesel exhaust on polycyclic aromatic hydrocarbon-induced DNA damage, gene expression and tumor initiation in Sencar mice in vivo. Cancer Letters, 265(1), 135-147. http://dx.doi.org/10.1016/j.canlet.2008.02.017

Djinovic, J., Popovic, A., \& Jira, W. (2008). Polycyclic aromatic hydrocarbons (PAHs) in different types of smoked meat products from Serbia. Meat Science, 80, 449-456. http://dx.doi.org/10.1016/j.meatsci.2008.01.008

EC (European Commission). (2003). Commission Regulation (EU) No 2065/2003 of the European Parliament and of the Council of 10 November 2003 on smoke flavourings used or intended for use in or on foods. Official Journal of the European Union, L 309, 1-8.

EC (European Commission). (2006). Commission Regulation (EU) № 1881/2006/EC of 19 December 2006 setting maximum levels for certain contaminants in foodstuffs. Off. J. Eur. Union, 364, 5-24.

EC (European Commission). (2011). Commission Regulation (EU) No 835/2011, of 19 August 2011, amending regulation (EC) No 1881/2006 as regards maximum levels for polycyclic aromatic hydrocarbons in foodstuffs. Off. J. Eur. Union, 215, 4-8.

EFSA (European Food Safety Authority). (2008). Polycyclic aromatic hydrocarbons in food - scientific opinion of the panel on contaminants in the food chain. EFSA J., 724, 1-114.

Elias, M., Agulheiro-Santos, A. C., \& Carrascosa, A. V. (2011). Improving quality in Iberian "Chouriço grosso" using autochthonous starter cultures. Fleischwirtsharft, 26(2), 87-90.

Elias, M., \& Carrascosa, A. V. (2010). Characterisation of the Paio do Alentejo, a traditional Portuguese Iberian sausage, in respect to its safety. Food Control, 21(1), 97-102. http://dx.doi.org/10.1016/j.foodcont.2009.04.004

Elias, M., \& Carrascosa, A. V. (2013). Physico-chemical, microbiological and sensory changes during storage in "Paio do Alentejo", a traditional Portuguese Iberian sausage. FleischWirtschaft International, 28, 128-133.

Elias, M., Marinho, A., Santos, A. C., Barreto, A., Oakinin, J., \& Ferreira, M. (2000). The influence of the autochthonous starter cultures on the production of regional sausages - Mechanical properties and sensorial evaluation. Proceedings of $46^{\text {th }}$ International Congress of Meat Science and Technology, Buenos Aires, Argentina. Vol. I, 230-231.

Elias, M., Marinho, A., Palma, V., Santos, C., \& Roseiro, L. C. (2003). The influence of the starter cultures in the production of regional Portuguese sausage - Microbiological, physical and chemical properties. Proceedings of $49^{\text {th }}$ International Congress of Meat Science and Technology, Campinas, Brazil.

Foegedinga, E. A., Brown, J., Drakea, M. A., \& Daubert, C. R. (2003). Review: Sensory and mechanical aspects of cheese texture. International Dairy Journal, 13, 585-591. http://dx.doi.org/10.1016/S0958-6946(03)00094-3

Friedman, H. H., Whitney, J. E., \& Szczesniak, A. S. (1963). The Texturometer - a new instrument for measurement. J. Food Sci., 28, 390-396. http://dx.doi.org/10.1111/j.1365-2621.1963.tb00216.x

Gomes, A., Santos, C., Almeida, J., Elias, M., \& Roseiro, L. C. (2013). Effect of fat content, casing type and smoking procedures on PAHs contents of Portuguese traditional dry fermented sausages. Food and Chemical Toxicology, 58, 369-374. http://dx.doi.org/10.1016/j.fct.2013.05.015

González, B., \& Díez, V. (2002). The effect of nitrite and starter culture on microbiological quality of "chorizo", a Spanish dry cured sausage. Meat Science, 60, 295-298. http://dx.doi.org/10.1016/S0309-1740(01)00137-1

González-Fernández, C., Santos, E. M., Rovira, J., \& Jaime, I. (2006). The effect of sugar concentration and starter culture on instrumental and sensory textural properties of chorizo - Spanish dry-cured sausage. Meat Science, 74, 467-475. http://dx.doi.org/10.1016/j.meatsci.2006.04.019

Haritash, A. K., \& Kaushik, C. P. (2009). Biodegradation aspects of Polycyclic Aromatic Hydrocarbons (PAHs): A review. Journal of Hazardous Materials, 169(1-3), 1-15. http://dx.doi.org/10.1016/j.jhazmat.2009.03.137 
Herrero A. M., Ordoñez J. A., de Avila, R., Herranz, B., de la Hoz, L., \& Cambero, M. I. (2007). Breaking strength of dry fermented sausages and their correlation with texture profile analysis (TPA) and $\begin{array}{lllll}\text { physico-chemical } \quad \text { characteristics. } & \text { Meat }\end{array}$ http://dx.doi.org/10.1016/j.meatsci.2007.03.022

Honikel, K. -O. (1997). Reference methods supported by OECD and their use in Mediterranean meat products. Food Chemistry, 59(4), 573-582. http://dx.doi.org/10.1016/S0308-8146(97)00002-2

Kanaly, R. A., \& Harayama, S. (2000). Biodegradation of High-Molecular-Weight Polycyclic Aromatic $\begin{array}{llllll}\text { Hydrocarbons by } & \text { Bacteria. } & J & \text { Bacteriol, } & 182(8), & \text { 2059-2067. }\end{array}$ http://dx.doi.org/10.1128/JB.182.8.2059-2067.2000

Lin, C. C., Chen, S. J., Huang, K. L., Lee, W. J., Lin, W. Y., \& Tsai, J. H. (2008). PAHs, PAH-induced carcinogenic potency, and particle-extract-induced cytotoxicity of traffic-related nano/ultrafine particles. Environmental Science \& Technology, 42(11), 4229-4235. http://dx.doi.org/10.1021/es703107w

Lorenzo, J. M., Purriños, L., Bermudez, R., Cobas, N., Figueiredo, M., \& García-Fontán, M. C. (2011). Polycyclic aromatic hydrocarbons (PAHs) in two Spanish traditional smoked sausage varieties: "Chorizo gallego" and "Chorizo de cebolla". Meat Science, 89(1), 105-109. http://dx.doi.org/10.1016/j.meatsci.2011.03.017

Marcos, B., Aymerich, T., Guardia, M. D., \& Garriga, M. (2007). Assessment of high hydrostatic pressure and starter culture on the quality properties of low-acid fermented sausages. Meat Science, 76, 46-53. http://dx.doi.org/10.1016/j.meatsci.2006.09.020

Martín, A., Colín, B., Aranda, E., Benito, M. J., \& Córdoba, M. G. (2007). Characterization of Micrococcaceae isolated from Iberian dry-cured sausages. Meat Science, 75, 696-708. http://dx.doi.org/10.1016/j.meatsci.2006.10.001

Martinez, O., Salmeron, J., Guillén, M. D., \& Casas, C. (2004). Texture profile analysis of meat products treated with commercial liquid smoke flavourings. Food Control, 15, 457-461. http://dx.doi.org/10.1016/S0956-7135(03)00130-0

Martín-Sánchez, A. M., Chaves-López, C., Sendra, E., Sayas, E., Fenández-López, J., \& Pérez-Álvarez, J. A. (2011). Lipolysis, proteolysis and sensory characteristics of a Spanish fermented dry-cured meat product (salchichón) with oregano essential oil used as surface mold inhibitor. Meat Science, 89(1), 35-44. http://dx.doi.org/10.1016/j.meatsci.2011.03.018

Moscoso, F., Teijiz, I., Deive, F. J., \& Sanromán, M. A. (2012). Efficient PAHs biodegradation by a bacterial consortium at flask and bioreactor scale. Bioresource Technology, 119, 270-276. http://dx.doi.org/10.1016/j.biortech.2012.05.095

Onega, E., Miguel, E., Blázquez, B., \& Ruiz de Huidobro, F. (2001). Relación entre algunos parámetros sensoriales e instrumentales de calidad de la carne de vacuno [Relationship between some sensory and instrumental parameters of bovine meat quality]. I Congreso Nacional de Ciencia y Tecnología de los Alimentos, Granada, p. 106.

Park, J. H., Gelhaus, S., Vedantam, S., Oliva, A. L., Batra, A., \& Blair, I. A. (2008). The pattern of p53 mutations caused by PAH o-quinones is driven by 8-oxo-dGuo formation while the spectrum of mutations is determined by biological selection for dominance. Chemical Research in Toxicology, 21, 1039-1049. http://dx.doi.org/10.1021/tx8003104

Perez-Alvarez, J. A., Sayas-Barberá, M. E., Fernández-López, J., \& Aranda-Catalá, V. (1999). Physicochemical characteristics of Spanish-type dry-cured sausage. Food Research International, 32, 599-607. http://dx.doi.org/10.1016/S0963-9969(99)00104-0

Pérez-Cacho, M. P. R., Galán-Soldevilla, H., Crespo, F. L., \& Recio, M. (2005). Determination of the Sensory Attributes of a Spanish dry-cured sausage. Meat Science, 71(4), 620-633. http://dx.doi.org/10.1016/j.meatsci.2005.05.005

Roseiro, L. C., Gomes, A., Gonçalves, H., Sol, M., Cercas, R., \& Santos, C. (2010). Effect of processing on proteolysis and biogenic amines formation in a Portuguese traditional dry-fermented ripened sausage "Chouriço Grosso de Estremoz e Borba PGI". Meat Science, 84(1), 172-179. http://dx.doi.org/10.1016/j.meatsci.2009.08.044

Roseiro, L. C., Gomes, A., \& Santos, C. (2011). Influence of processing in the prevalence of polycyclic aromatic hydrocarbons in a Portuguese traditional meat product. Food Chem. Toxicol, 49, 1340-1345. http://dx.doi.org/10.1016/j.fct.2011.03.017

Roseiro, L. C., Santos, C., Sol, M., Borges, M. J., Anjos, M., \& Gonçalves, H. (2008). Proteolysis in Painho de 
Portalegre dry fermented sausage in relation to ripening time and salt content. Meat Science, 79(4), 784-794. http://dx.doi.org/10.1016/j.meatsci.2007.11.012

Rubio, B., Martínez, B., Sánchez, M. J., García-Cachán, M. D., Rovira, J., \& Jaime, I. (2007). Study of the shelf life of a dry fermented sausage "salchichon" made from raw material enriched in mono-unsaturated and poly-unsaturated fatty acids and stored under modified atmospheres. Meat Science, 76, 128-137. http://dx.doi.org/10.1016/j.meatsci.2006.10.021

Ruiz de Huidobro, F., Caneque, V., Lauzurica, S., Velasco, S., Pérez, C., \& Onega, E. (2001). Sensory characterization of meat texture in sucking lambs. Methodology. Investigación Agraria: Producción y Sanidad Animales, 16(2), 223-234.

Ruiz de Huidobro, F., Miguel, E., Blázquez, B., \& Onega, E. (2005). A comparison between two methods (Warner-Bratzler and texture profile analysis) for testing either raw meat or cooked meat. Meat Science, 69, 527-536. http://dx.doi.org/10.1016/j.meatsci.2004.09.008

Santos, C., Gomes, A., \& Roseiro, L. C. (2011). Polycyclic aromatic hydrocarbons incidence in Portuguese traditional smoked meat products. Food Chem. Toxicol, 49, 2343-2347. http://dx.doi.org/10.1016/j.fct.2011.06.036

Santos, E. M., González-Fernández, C., Jaime, I., \& Rovira, J. (2003). Physico-chemical and sensory characterisation of Morcilla de Burgos, a traditional Spanish blood sausage. Meat Science, 65, 893-898. http://dx.doi.org/10.1016/S0309-1740(02)00296-6

Simion, A. M. C., Vizireanu, C., Alexe, P., Franco, I., \& Carballo, J. (2014). Effect of the use of selected starter cultures on some quality, safety and sensorial properties of Dacia sausage, a traditional Romanian dry-sausage variety. Food Control, 35, 123-131. http://dx.doi.org/10.1016/j.foodcont.2013.06.047

Spaziani, M., del Torre, M., \& Stecchini, M. L. (2009). Changes of physico-chemical, microbiological, and textural properties during ripening of Italian low-acid sausages. Proteolysis, sensory and volatile profiles. Meat Science, 81, 77-85. http://dx.doi.org/10.1016/j.meatsci.2008.06.017

Stumpe-Vīksna, I., Bartkevičs, V., Kukāre, A. \& Morozovs, A. (2008). Polycyclic aromatic hydrocarbons in meat smoked with different types of wood. Food Chem. (110), 794-797. http://dx.doi.org/10.1016/j.foodchem.2008.03.004

Szczesniak, A. S. (2002). Texture is a sensory property. Food Quality and Preference, 13, 215-225. http://dx.doi.org/10.1016/S0950-3293(01)00039-8

Szczesniak, A. S., Brandt, M. A., \& Friedman, H. H. (1963). Development of standard rating scales for mechanical parameters of texture and correlation between the objective and sensory methods of texture evaluation. J. Food. Science, 28, 397-403. http://dx.doi.org/10.1111/j.1365-2621.1963.tb00217.x

Tian, Y., Luo, Y., Zheng, T., Cai, L., Cao, X., \& Yan, C. (2008). Contamination and potential biodegradation of polycyclic aromatic hydrocarbons in mangrove sediments of Xiamen, China. Marine Pollution Bulletin, 56(6), 1184-1191. http://dx.doi.org/10.1016/j.marpolbul.2008.02.014

Wang, S., Nomura, N., Nakajima, T., \& Uchiyama, H. (2012). Case study of the relationship between fungi and bacteria associated with high-molecular-weight polycyclic aromatic hydrocarbon degradation. Journal of Bioscience and Bioengineering, 113(5), 624-630. http://dx.doi.org/10.1016/j.jbiosc.2012.01.005

Wang, P., Xu, X. L., \& Zhou, G. H. (2009). Effects of Meat and Phosphate Level on Water-Holding Capacity and Texture of Emulsion-Type Sausage During Storage. Agricultural Sciences in China, 8(12), 1475-1481. http://dx.doi.org/10.1016/S1671-2927(08)60361-2

Yang, H. -S., Choi, S. -G., Jeon, J. -T., Park, G. -B., \& Joo, S. -T. (2007). Textural and sensory properties of low fat pork sausages with added hydrated oatmeal and tofu as texture-modifying agents. Meat Science, 75(2), 283-289. http://dx.doi.org/10.1016/j.meatsci.2006.07.013

\section{Copyrights}

Copyright for this article is retained by the author(s), with first publication rights granted to the journal.

This is an open-access article distributed under the terms and conditions of the Creative Commons Attribution license (http://creativecommons.org/licenses/by/3.0/). 